\title{
Characterisation of metal/mould interface on investment casting of $\gamma$-TiAl
}

\author{
J. Barbosa ${ }^{1}$, H. Puga ${ }^{2}$, C. S. Ribeiro*2, O. M. N. D. Teodoro ${ }^{3}$ and A. C. Monteiro ${ }^{1}$
}

This paper describes the evaluation of different refractory compounds - $\mathrm{SiO}_{2}, \mathrm{ZrO}_{2}$ and $\mathrm{Y}_{2} \mathrm{O}_{3}-$ as face coats of investment casting shells for $\gamma$-TiAl.

The effect of the different refractories on the metal-mould interaction is studied in different aspects. Experimental results include characterisation of the constituents present at the metal/ mould interface, the segregation profiles of residual elements, namely oxygen, from the interface to the inner part of the samples, the extension and microhardness of the samples external hard case and the samples surface finishing.

Keywords: TiAl, Investment casting, Ceramic mould, Zirconia, Yttria, Silica, Graphite, Ceramic crucible

\section{Introduction}

The present application fields of titanium castings involve the production of high geometrical and dimensional precision castings, i.e. near net shape parts, demanding the use of high capability moulding processes and moulding materials with good thermal and chemical stability and refractoriness. During the last decades, ceramics aroused as the best moulding materials to produce near net shape castings, using the investment casting process. However, its use with titanium castings presents some drawbacks, owing to the high reactivity of the alloys, especially with oxygen, mainly at temperatures $>500^{\circ} \mathrm{C}$. Titanium alloys have low fluidity, so they require a significant amount of superheating, which increases the temperature at the metal/mould interface and consequently the alloyrefractory interaction effect.

Different phenomena can be associated to the metalmould interaction ${ }^{1}$ on investment casting, which effectiveness depends on the nature of the pair metal mould material and the pouring parameters. When casting titanium alloys using the investment casting process the most frequent phenomena is the reaction or/and dissolution of the mould materials by the molten metal. Immediately after pouring, the liquid metal starts to interact with the mould materials and may dissolve or/ and react with them, depending on its thermodynamic stability and the kinetics of a possible reaction. On this phase, the interaction products may dissolve in liquid metal, leading to a quite uniform distribution of residual elements. When solidification starts, diffusion mechanisms become very slow and if the metal-mould interaction persists, then a gradient of composition may appear

${ }^{1}$ Departamento de Engenharia Mecânica, Universidade do Minho, Guimarães, Portugal

${ }^{2}$ Departamento de Eng. Metalúrgica e de Materiais, FEUP, Porto, Portugal ${ }^{3}$ CEFITEC, Departamento de Física da Faculdade de Ciências e Tecnologia, Universidade Nova de Lisboa, Caparica, Portugal

*Corresponding author, email sribeiro@fe.up.pt from the surface to the inside of the casting. When a reaction occurs, the reaction products may appear at the casting surface (if they are not soluble in the liquid metal or their dissolution rate is very small), or they dissolve rapidly and they will not be detected (as it happens with $\mathrm{TiO}$ and $\mathrm{TiO}_{2}$, that dissolve very fast in liquid titanium, increasing its overall oxygen content).

Titanium castings usually reveal a strong oxygen content variation, decreasing from the surface to the inner part of the casting, owing to the oxygen pickup from the mould wall and its diffusion to the inside, even after solidification starts. This variation is usually followed through a hardness variation under a similar profile, as it is well know the direct relationship between both parameters. ${ }^{1-4}$ In practice, titanium castings usually present a hard case at the outer surface, that some call 'alpha-case', which must be removed by 'chemical milling' before its industrial application.

This paper describes the work developed by the authors concerning the use of several moulding materials on the production of $\gamma$-TiAl samples by investment casting, using a multilayer technique, with the purpose to develop a moulding technique that could allow the production of castings without or with reduced extension of 'alpha-case'.

\section{Experimental technique}

\section{Materials selection}

The selection of moulding materials was based on the experience formerly acquired by the authors to develop a melting crucible suitable to melt titanium based alloys. ${ }^{2,3,5}$ However, while melting crucibles are usually made of a single refractory material, moulding materials, namely those used on the investment casting process, include both a refractory and a binder, which must be inert against the melting alloy. Although the authors know that the extension of any reaction also depends upon the kinetic behaviour, for a particular system and temperature, the scarcity of data available take these experiments based only on the free energy of formation

(C) 2006 W. S. Maney \& Son Ltd. 


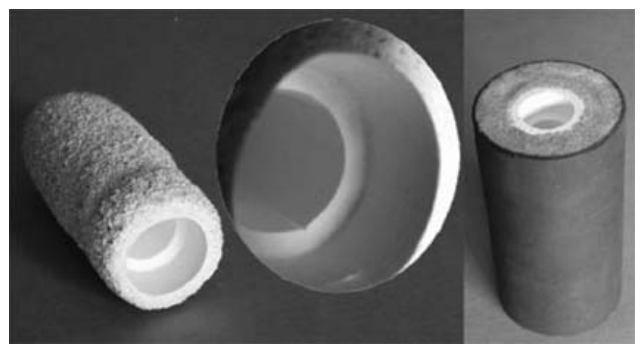

1 Ceramic mould used to pour Ti-48AI

of the simple oxides. According with the standard free energies of formation of metallic oxides, several oxides are thermodynamically more stable than those that might form from $\mathrm{Ti}$ and $\mathrm{Al}$ (mainly $\mathrm{TiO}_{2}, \mathrm{TiO}$ and $\mathrm{Al}_{2} \mathrm{O}_{3}$ ), namely $\mathrm{MgO}, \mathrm{CaO}, \mathrm{ZrO}_{2}$ and $\mathrm{Y}_{2} \mathrm{O}_{3}$, which may be a good choice to produce ceramic moulds. Although there are some good references to the use of $\mathrm{CaO}$ as crucible material for $\mathrm{TiAl},{ }^{6,7}$ it was not selected due to its high higroscopicity and difficult handling practice. Owing to its low thermal shock resistance, also $\mathrm{MgO}$ was not evaluated. Work was carried on using $\mathrm{ZrO}_{2}$ and $\mathrm{Y}_{2} \mathrm{O}_{3}$, and $\mathrm{SiO}_{2}$ moulds were also evaluated, for the sake of comparison.

\section{Moulds production}

TiAl test samples were cylinders $20 \mathrm{~mm}$ in diameter and $85 \mathrm{~mm}$ long. The production of $\mathrm{ZrO}_{2}, \mathrm{Y}_{2} \mathrm{O}_{3}$ and $\mathrm{SiO}_{2}$ ceramic shells was performed using traditional dip coating/stuccoing techniques. In order to decrease production costs, $\mathrm{Y}_{2} \mathrm{O}_{3}$ shells were in fact multilayered $\mathrm{ZrO}_{2}$ based shells, with a $\mathrm{Y}_{2} \mathrm{O}_{3}$ face coat, produced by using two layers of a $\mathrm{Y}_{2} \mathrm{O}_{3}$ slurry (consisting of colloidal $\mathrm{Y}_{2} \mathrm{O}_{3}+\mathrm{Y}_{2} \mathrm{O}_{3}$ powder refractory) and external coatings made of $\mathrm{ZrO}_{2}$ slurries and $\mathrm{ZrO}_{2}$ refractory (Table 1). After firing at $1100^{\circ} \mathrm{C}$ during $4 \mathrm{~h}$, shells were positioned inside a cylindrical metallic box and fixed by filling the remaining space inside the box with sodium silicate $/ \mathrm{CO}_{2}$ moulding sand (Fig. 1).

\section{Melting and Pouring}

A Ti-48Al alloy was selected for melting, prepared from commercially pure titanium and aluminium. Melting was carried out by induction melting on a $\mathrm{ZrO}_{2}$ based ceramic crucible, with an inside layer of $\mathrm{Y}_{2} \mathrm{O}_{3}$, and moulds were centrifugally poured $\sim 1600^{\circ} \mathrm{C}$, according to a technique described elsewhere., ${ }^{2,5}$ The entire processing was performed inside a sealed chamber, where a controlled atmosphere of commercial pure argon was maintained.

\section{Samples characterisation}

Samples for characterisation were collected from the middle of the cast cylinders, by sectioning them at 50\%

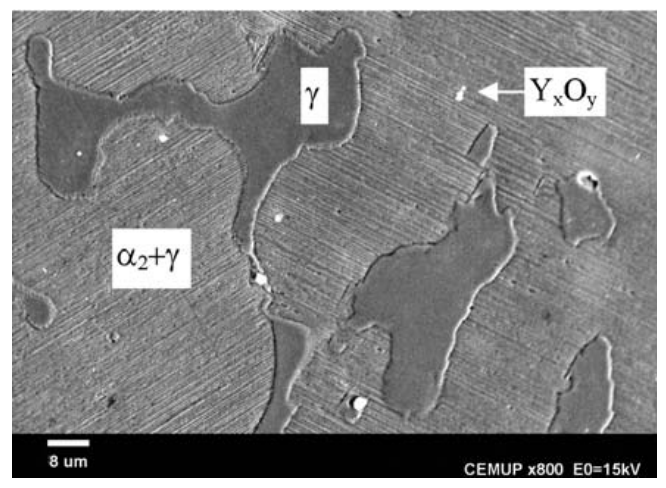

2 Microstructure of $\mathrm{Ti}-48 \mathrm{Al}$ sample cast in $\mathrm{ZrO} 2$ mould, revealing traditional $\alpha_{2}+\gamma / \gamma$ microstructure and a few yttrium oxide inclusions

of their height. They were prepared using traditional metallographic techniques: surfaces were mechanically polished and etched with Kroll solution $(2 \% \mathrm{HF}$, $\left.4 \% \mathrm{HNO}_{3}, 94 \% \mathrm{H}_{2} \mathrm{O}\right)$. Phase identification and chemical composition were performed by quantitative EDS analysis with standards of pure $\mathrm{Ti}, \mathrm{Al}, \mathrm{Zr}$ and $\mathrm{Y}$ using a JEOL JSM 35C scanning electron microscope. A $10 \mathrm{keV}$ potential and a $100 \mathrm{~s}$ acquisition time were used. Overall oxygen content was measured by the inert gas fusion (IGF) technique and secondary ion mass spectrometry was used to determine the diffusion profile of oxygen $^{9,10}$ from the surface to the inside of the samples. X-ray diffraction (XRD) was used to identify compounds present on the metal/mould interface. Microhardness was evaluated on a Shimadzu hardness tester, using a $50 \mathrm{~g}$ load for $15 \mathrm{~s}$. The surface roughness of the samples was measured on a Perthometer S5P.

\section{Experimental results}

The microstructure of every cast sample contains two microconstituents: one with a strong dendritic pattern, with two phases $\left(\alpha_{2}+\gamma\right)$ and a $\gamma$ interdendritic phase (Fig. 2). The dendritic constituent is present in a higher quantity in every sample and represents an average volume fraction $\sim 90 \%$, which is a little lower at the samples surface, following the increase in the cooling rate. Some yttrium oxide inclusions can be found dispersed on the metallic matrix (Fig. 3), which origin it is believed to be the erosion of the $\mathrm{Y}_{2} \mathrm{O}_{3}$ coating of the melting crucible during melting.

\section{$\mathrm{ZrO}_{2}$ mould}

Concerning the samples chemical composition, no $\mathrm{Zr}$ was found in the lamellar constituent, but the $\gamma$ interdendritic phase reveals a high $\mathrm{Zr}$ content at the sample surface $(0 \cdot 51$ at. $\%$ at $25 \mu \mathrm{m}$ from the surface and decreases up to $0 \cdot 32$ at. $-\%$ at $50 \mu \mathrm{m}$ from the same,

Table 1 Composition of ceramic shells used on this work

\begin{tabular}{|c|c|c|c|c|c|c|}
\hline & \multicolumn{3}{|l|}{ Face coatings } & \multicolumn{3}{|c|}{ Backup coatings } \\
\hline & \multicolumn{2}{|l|}{ Slurry } & \multirow[b]{2}{*}{ Refractory } & \multicolumn{2}{|l|}{ Slurry } & \multirow[b]{2}{*}{ Refractory } \\
\hline & Binder & Refractory & & Binder & Refractory & \\
\hline $\begin{array}{l}\mathrm{ZrO}_{2} \\
\mathrm{Y}_{2} \mathrm{O}_{3} \\
\mathrm{SiO}_{2}\end{array}$ & $\begin{array}{l}\text { Colloidal } \mathrm{ZrO}_{2} \\
\text { Colloidal } \mathrm{Y}_{2} \mathrm{O}_{3} \\
\text { Colloidal } \mathrm{SiO}_{2}\end{array}$ & $\begin{array}{l}\mathrm{ZrO}_{2} \\
\mathrm{Y}_{2} \mathrm{O}_{3} \\
\mathrm{SiO}_{2}\end{array}$ & $\begin{array}{l}\mathrm{ZrO}_{2} \\
\mathrm{Y}_{2} \mathrm{O}_{3} \\
\mathrm{SiO}_{2}\end{array}$ & $\begin{array}{l}\text { Colloidal } \mathrm{ZrO}_{2} \\
\text { Colloidal } \mathrm{ZrO}_{2} \\
\text { Colloidal } \mathrm{SiO}_{2}\end{array}$ & $\begin{array}{l}\mathrm{ZrO}_{2} \\
\mathrm{ZrO}_{2} \\
\mathrm{SiO}_{2}\end{array}$ & $\begin{array}{l}\mathrm{ZrO}_{2} \\
\mathrm{ZrO}_{2} \\
\mathrm{SiO}_{2}\end{array}$ \\
\hline
\end{tabular}




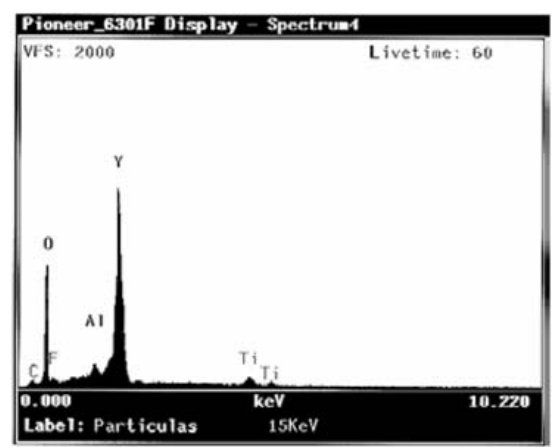

3 Spectrum (EDS) of $\mathrm{Y}_{\mathrm{x}} \mathrm{O}_{\mathrm{y}}$ inclusion referred in Fig. 2

becoming lower than the equipment detection limit $(0 \cdot 10$ at. $-\%$ at higher distances). The cast alloy reveals a small contamination with yttrium $(0 \cdot 1$ at. $-\%)$, owing to the fact that the melt was performed in a $\mathrm{Y}_{2} \mathrm{O}_{3}$ coated ceramic crucible, which is in accordance with results previously obtained by the authors. ${ }^{2,3,5}$ The overall oxygen content of the alloy, measured by IGF, is $0 \cdot 27 \mathrm{wt}-\%$. Considering the oxygen content of the elements of the melting charge, the estimated oxygen content on the original melting charge is $\sim 0.15 \mathrm{wt}-\%$, and the increase on the oxygen content due to the melting operation is $\sim 0 \cdot 15 \mathrm{wt}-\%{ }^{2,3}$ As the oxygen content of the alloy is only $0 \cdot 27 \mathrm{wt}-\%$, it can be assumed that the use of $\mathrm{ZrO}_{2}$ as mould material does not affect the oxygen overall content of the sample.

The samples microhardness has a constant mean value of $289 \pm 7 \mathrm{HV}$ on the $\gamma$ interdendritic phase, all over the sample. However, on the lamellar constituent, it increases from $301 \pm 5 \mathrm{HV}$ at distances from the sample surface $>75 \mu \mathrm{m}$, up to $362 \mathrm{HV}$ at $25 \mu \mathrm{m}$ (Fig. 4), resulting on an 'alpha-case' extension of $75 \mu \mathrm{m}$ for this cast sample. The hardness increase on the $\alpha_{2}+\gamma$ constituent at the sample surface is believed to be caused by the increase of the alloy oxygen content in the same region (Fig. 5). In fact, the oxygen concentration and the $\alpha_{2}+\gamma$ microhardness variation profiles from the surface of samples, to the inside, are quite similar and match almost perfectly, suggesting their close dependence (the oxygen concentration decreases from the sample surface to the inside of it and becomes almost

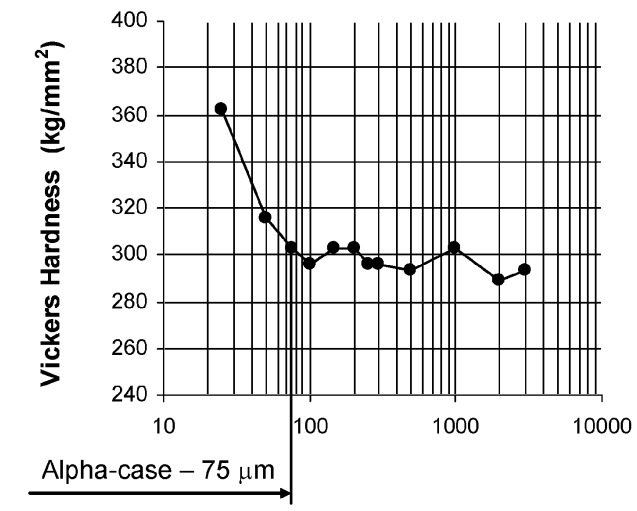

(a)

Depth from surface $(\mu \mathrm{m})$

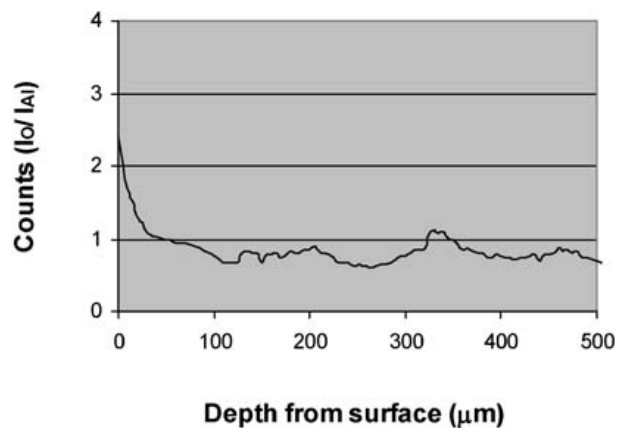

5 Oxygen concentration profile from surface to inside of Ti-48Al sample cast in $\mathrm{ZrO}_{2}$ mould

constant, although revealing some fluctuations, at distances from the surface higher than those on the interval between 75 and $100 \mu \mathrm{m}$ ). This effect is only detected on the lamellar constituent because in $\gamma$-TiAl alloys the oxygen fixes essentially on the $\alpha_{2}$ phase where its solubility limit is $\sim 21600 \mathrm{ppm}$, whereas in the $\gamma$ phase that value is only $230 \mathrm{ppm} .{ }^{10,11}$ Thus, the oxygen content variation curve obtained by secondary ion mass spectrometry (Fig. 5) represents in fact the variation of the oxygen content on the $\alpha_{2}$ phase with the distance at the sample surface and it can be qualitatively correlated with the $\alpha_{2}+\gamma$ microhardness variation curve for the same region.

Figure $6 a$ shows the microstructure of the sample surface (metal/mould interface) and clearly reveals the presence of an oxide film (continuous on its outside and discontinuous on its inside), $\sim 15 \mu \mathrm{m}$ thick, that the EDS spectrum identifies as an aluminium oxide and the XRD spectrum of the sample surface region (Fig. 6b) suggests be $\mathrm{Al}_{2} \mathrm{O}_{3}$. According to the Ellingham diagrams (Fig. 7), it is not expected that both $\mathrm{Ti}$ and $\mathrm{Al}$ might reduce the $\mathrm{ZrO}_{2}$ mould material as, at the pouring temperature, this compound is thermodynamically more stable than any $\mathrm{Ti}$ and $\mathrm{Al}$ oxide. Although, when the molten metal enters the mould cavity it may dissolve the $\mathrm{ZrO}_{2},{ }^{12,13}$ and the diffusion of $\mathrm{Zr}$ and $\mathrm{O}$ in the alloy starts. When solidification starts, the $\mathrm{ZrO}_{2}$ dissolution rate becomes much slower, as well as the diffusion mechanisms, leading to the $\mathrm{Zr}$ and $\mathrm{O}$ concentration

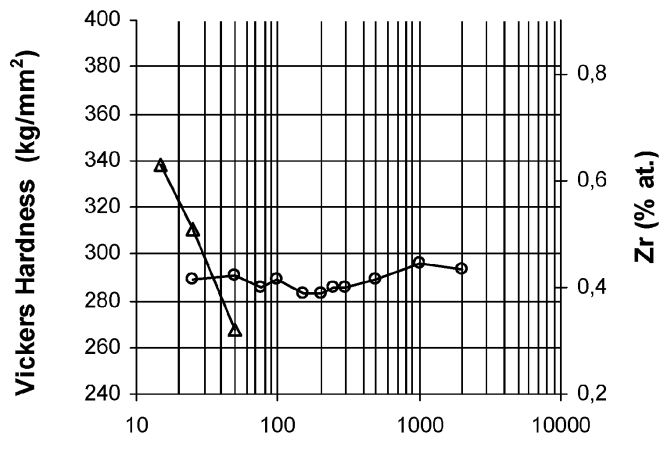

Depth from surface $(\mu \mathrm{m})$

(b)

$$
\rightarrow \operatorname{HV}\left(\alpha_{2}+\gamma\right) \quad-0-\operatorname{HV}(\gamma) \quad-\Delta \text { at } \% \operatorname{Zr}(\gamma \text { phase })
$$

$a \alpha_{2}+\gamma$ constituent; $b$ interdendritic $\gamma$ phase

4 Microhardness and Zr concentration profiles from surface to inside of Ti-48Al sample cast in ZrO2 mould 

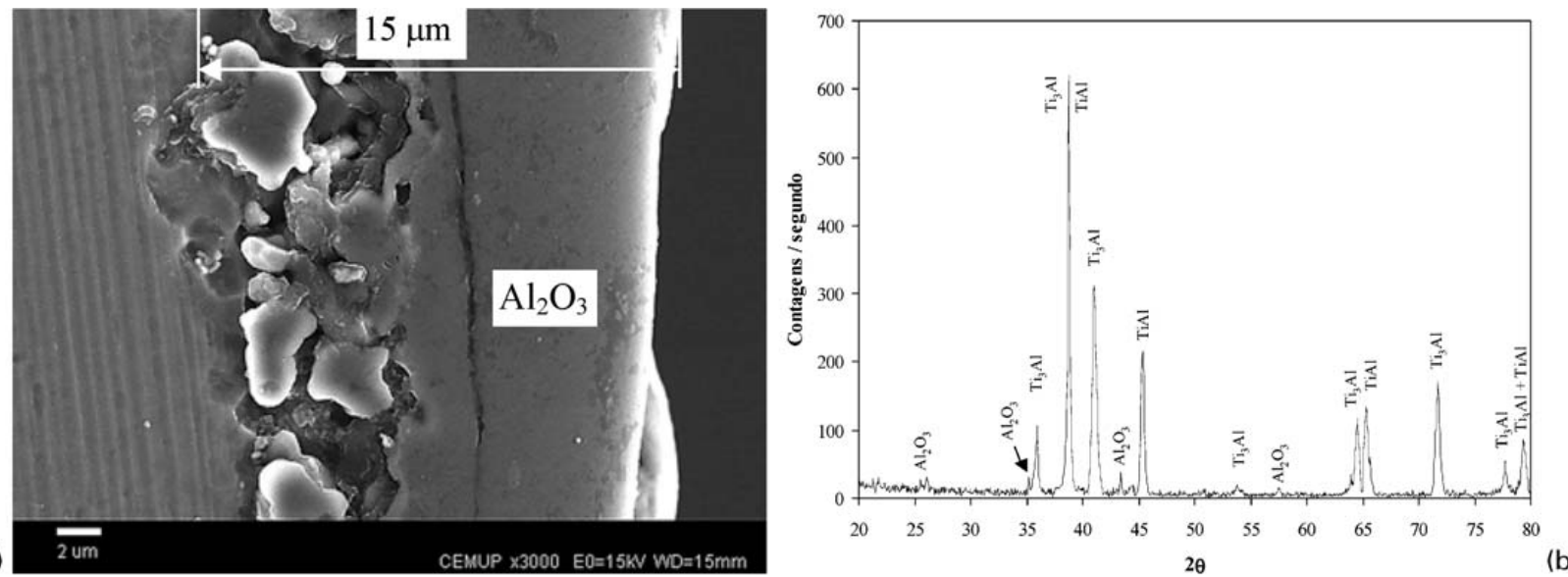

6 a microstructure of surface (metal/mould interface) of $\mathrm{Ti}-48 \mathrm{Al}$ sample obtained in $\mathrm{ZrO}_{2} \mathrm{mould}$ where $\mathrm{Al} 2 \mathrm{O} 3$ layer can be seen and $b$ XRD spectrum obtained at surface of sample cast in $\mathrm{ZrO}_{2}$ mould, revealing presence of $\mathrm{Al}_{2} \mathrm{O}_{3}$

gradients illustrated in Figs. 4 and 5. Owing to the decrease in the diffusion rate, the $\mathrm{O}$ content at the interface is very high during this period and leads to the formation of $\mathrm{Al}$ oxides at the casting surface. As the sample temperature drops, the diffusion of $\mathrm{Zr}$ and $\mathrm{O}$ stops, but as the oxygen atom is much smaller than the $\mathrm{Zr}$ atom, the diffusion depth of this element $(50 \mu \mathrm{m}$, Fig. 4) is significantly smaller than the $\mathrm{O}$ diffusion depth $\left(100 \mu \mathrm{m}\right.$, Fig. 5). When temperature reaches $750^{\circ} \mathrm{C}$ and the sample is already solidified the thermodynamic stability of $\mathrm{Al}_{2} \mathrm{O}_{3}$ and $\mathrm{ZrO}_{2}$ is inverted and $\mathrm{Al}_{2} \mathrm{O}_{3}$ becomes more stable than $\mathrm{ZrO}_{2}$ for lower temperatures (Fig. 7). For this reason, a reaction between the mould material and the aluminium from the TiAl alloy is possible to occur and continue as temperature is dropping, with formation of $\mathrm{Al}_{2} \mathrm{O}_{3}$ (according to the reaction (1)), leading to the development of a perfectly continuous oxide film, as illustrated in Fig. $6 a$. On the other hand, such reaction might explain the decrease on the $\mathrm{Al}$ content at the casting surface revealed by the EDS analysis (at $15 \mu \mathrm{m}$ from the casting surface, the $\mathrm{Al}$ content of the lamellar constituent is $40 \cdot 15 \mathrm{wt}-\%$, but the average value on that constituent all over the sample is $46 \cdot 3 \mathrm{wt}-\%)$

$$
4 \mathrm{Al}+3 \mathrm{ZrO}_{2}=2 \mathrm{Al}_{2} \mathrm{O}_{3}+3 \mathrm{Zr}
$$

A thin layer of moulding material can be seen adherent to the sample surface, which is easily removed

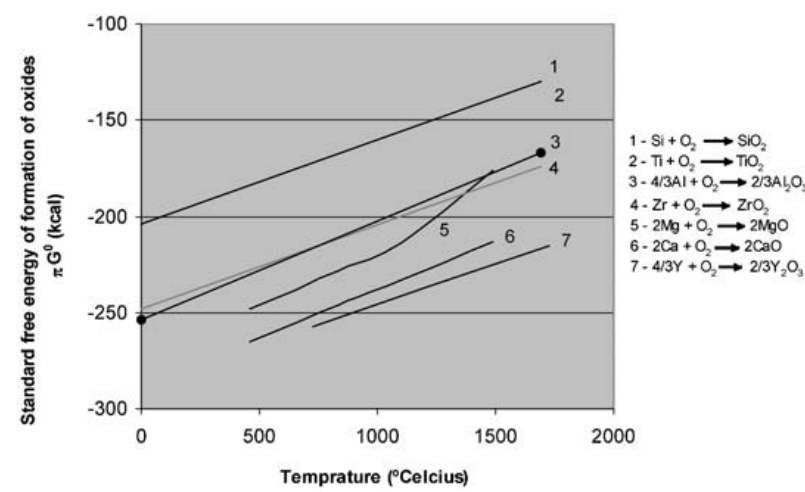

7 Standard free energy of formation of several oxides, including $\mathrm{TiO}$, showing inversion on relative stability of $\mathrm{ZrO}_{2}$ and $\mathrm{Al}_{2} \mathrm{O} 3$ at temperature $\sim 750^{\circ} \mathrm{C}$ with a finger. Average roughness of the sample surface is $2 \cdot 1 \mu \mathrm{m}$ (Fig. 8).

\section{$\mathrm{Y}_{2} \mathrm{O}_{3}$ mould}

Samples obtained in $\mathrm{Y}_{2} \mathrm{O}_{3}$ coated $\mathrm{ZrO}_{2}$ based moulds reveal a small contamination with $\mathrm{Y}$ and $\mathrm{O}$ near the surface, as illustrated in Figs. 9 and 10, revealing that the yttria film is not absolutely inert against the molten alloy. According to its thermodynamic stability, it is not predictable that $\mathrm{Y}_{2} \mathrm{O}_{3}$ might be reduced by the TiAl alloy, what suggests that the presence of $\mathrm{Y}$ and $\mathrm{O}$ at the casting surface is due to a slight dissolution of the coating by the molten alloy. The oxygen overall content of the sample, measured by the IGF technique, is $0.29 \mathrm{wt}-\%$ and the yttrium content is 0.11 at. $-\%$, which result from the melting operation itself, as verified in previous work. ${ }^{1,2}$ This fact means that the moulding material dissolution only affects a very small thickness of metal $(25 \mu \mathrm{m}$ as illustrated in Figs. 9 and 10 , where the $\mathrm{Y}$ and $\mathrm{O}$ contents become a little higher that the average values inside the sample).

Inside the samples average microhardness values are $299 \pm 8 \mathrm{HV}$ on $\alpha_{2}+\gamma$ and $291 \pm 5 \mathrm{HV}$ on the $\gamma$
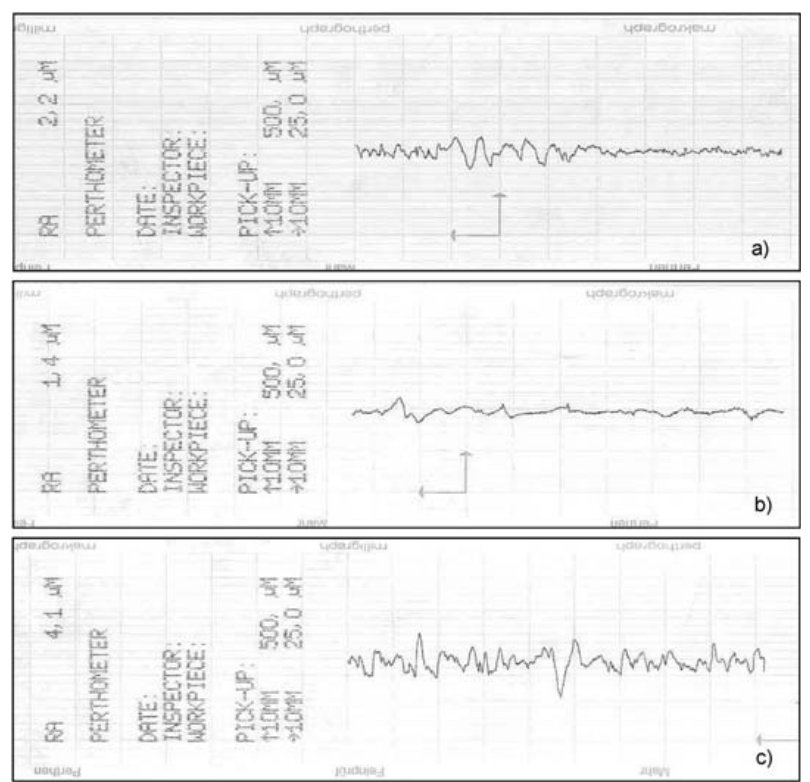

8 Surface roughness profiles of Ti-48Al samples cast in a $\mathrm{ZrO} 2$ mould, $b$ Y2O3 mould and $c \mathrm{SiO}_{2}$ mould

International Journal of Cast Metals Research 2006 VOL 19 NO 6 


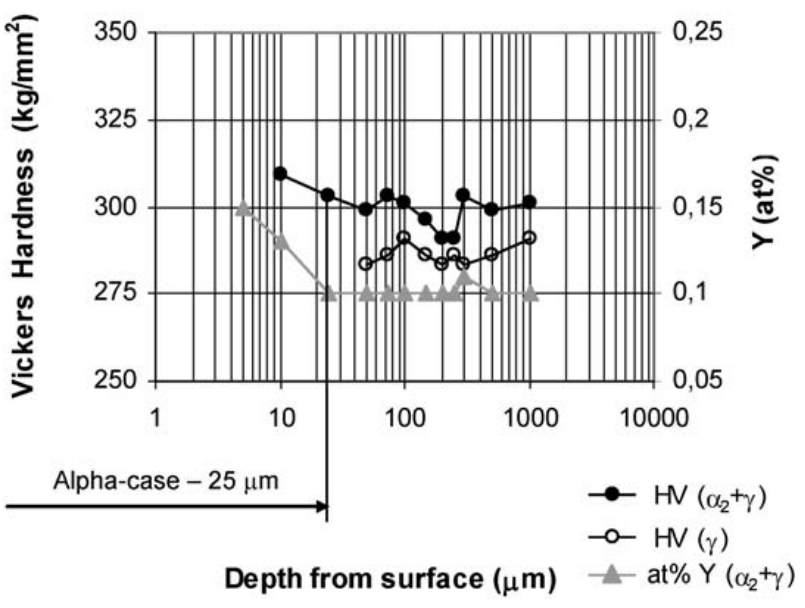

9 Microhardness and $Y$ concentration profiles from surface to inside of $\mathrm{Ti}-48 \mathrm{Al}$ sample cast in $\mathrm{Y}_{2} \mathrm{O}_{3}$ coated zirconia mould

interdendritic phase. Microhardness values are a little higher at the samples surface, on the $\alpha_{2}+\gamma$ microconstituent (309 $\mathrm{HV}$ at $10 \mu \mathrm{m}$ from the surface), but no significant change was detected on the $\gamma$ interdendritic phase (Fig. 9). $\alpha_{2}+\gamma$ microhardness and oxygen concentration variation profiles from the surface to the inside of samples are similar and match quite well, suggesting once more, its close dependence. The 'alphacase' extension is $25 \mu \mathrm{m}$ on these samples and agrees with values referred by Feagin ${ }^{14}$ for Ti-6Al-4V samples obtained in $\mathrm{Y}_{2} \mathrm{O}_{3}$ moulds, although the author refers peak values of $2.5 \mu \mathrm{m}$.

Figure 11 shows the sample microstructure at the surface (metal/mould interface), where a thin oxide film $(<1 \mu \mathrm{m})$ that the EDS spectrum (Fig. 12) suggests be $\mathrm{Y}_{2} \mathrm{O}_{3}$ detached from the mould surface can be seen, but no change in the matrix microstructure is evident. The thin $\mathrm{Y}_{2} \mathrm{O}_{3}$ film is not adherent to the metal and can be easily removed with a finger. The sample reveals a completely clean surface, without adherent mould material. The surface roughness was measured in different areas and the average $\mathrm{Ra}$ is $1.6 \mu \mathrm{m}$ (Fig. 8), which is similar to traditional investment castings.

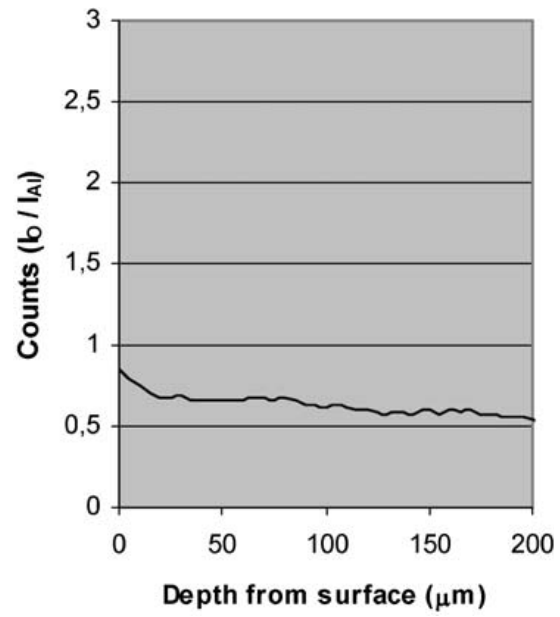

10 Oxygen concentration profile from surface to inside of Ti-48Al sample cast in $\mathrm{Y}_{2} \mathrm{O}_{3}$ coated zirconia mould

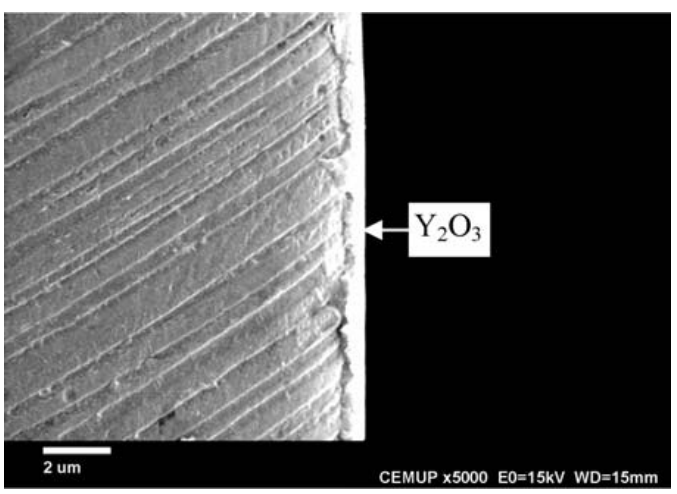

11 Microstructure of surface (metal/mould interface) of Ti-48Al sample obtained in $\mathrm{Y}_{2} \mathrm{O}_{3}$ coated zirconia mould, showing thin adherent layer of $\mathrm{Y}_{2} \mathrm{O}_{3}$

\section{$\mathrm{SiO}_{2}$ mould}

Samples cast in $\mathrm{SiO}_{2}$ based investment shells reveal as expected a significant contamination with $\mathrm{Si}$ at the surface, in both microconstituents (Fig. 13). In $\alpha_{2}+\gamma$, the Si content decreases from a value of 0.53 at. $-\%$ at $25 \mu \mathrm{m}$ from the samples surface to values $<0 \cdot 1$ at. $-\%$ at distances $>100 \mu \mathrm{m}$. In the $\gamma$ interdendritic phase, the $\mathrm{Si}$ content is slightly higher, as well as its diffusion depth. Si content decreases from 0.83 at. $\%$ at $25 \mu \mathrm{m}$ from the surface until values $<0 \cdot 1$ at. $-\%$, at distances $>150 \mu \mathrm{m}$. Although the alloy contamination is quite important, the $\mathrm{Si}$ concentration is lower than referred by other researchers when a $\mathrm{Ti}$ alloy is allowed to cool to room temperature in contact with $\mathrm{SiO}_{2}$, either as refractory material or as a binder. ${ }^{13}$ As it happens in every other samples, the alloy presents a contamination with $\mathrm{Y}$ $\sim 0.1$ at. $-\%$, which is due to the melting operation, as explained in sections ' $\mathrm{ZrO}_{2}$ mould' and ' $\mathrm{Y}_{2} \mathrm{O}_{3}$ mould'. The oxygen concentration profile from the surface to the inner part of the samples shows a similar development to the profile detected in those samples cast in $\mathrm{Y}_{2} \mathrm{O}_{3}$ and $\mathrm{ZrO}_{2}$ moulds, although the diffusion depth is much higher in this case $-250 \mu \mathrm{m}$ (Fig. 14). The difference detected in the oxygen diffusion depth in different mould materials can only be explained by different dissolution rates/kinetics of each mould material in the molten alloy. In fact, cooling time/speed is similar in every cast sample and does not change much between the mould materials that were used.

Figure 15 illustrates one sample microstructure at the surface (metal/mould interface), where an oxide layer with thickness between 20 and $50 \mu \mathrm{m}$, can be seen. The

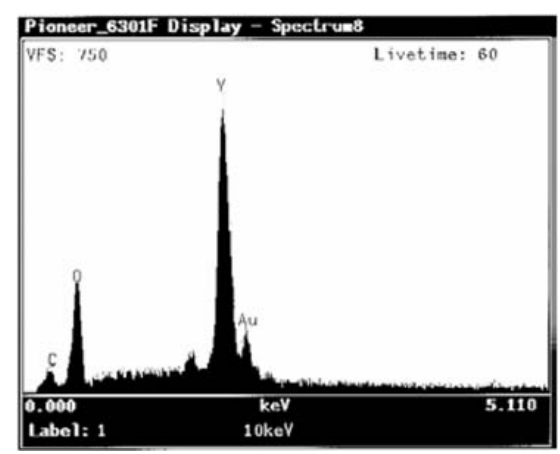

12 Spectrum EDS of $\mathrm{Y}_{\mathrm{x}} \mathrm{O}_{\mathrm{y}}$ layer present at surface of $\mathrm{Ti}-$ 48Al sample cast in $\mathrm{Y}_{2} \mathrm{O}_{3}$ coated zirconia mould 


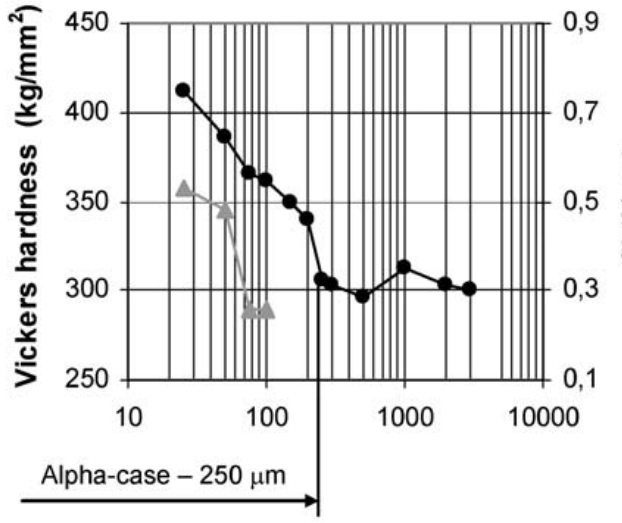

Depth from surface $(\mu \mathrm{m})$

(a) $\rightarrow \mathrm{HN} \quad-$ at\% $\mathrm{Si}$

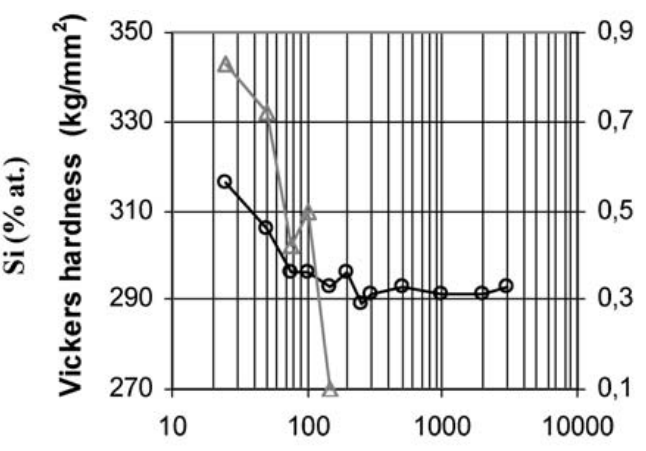

Depth from surface $(\mu \mathrm{m})$

$\rightarrow-\mathrm{HN} \quad-\triangle-$ at\% Si

(b)

$a \alpha_{2}+\gamma$ constituent; $b$ interdendritic $\gamma$ phase

13 Microhardness and $\mathrm{Zr}$ concentration profiles from surface to inside of Ti-48Al sample cast in SiO2 mould

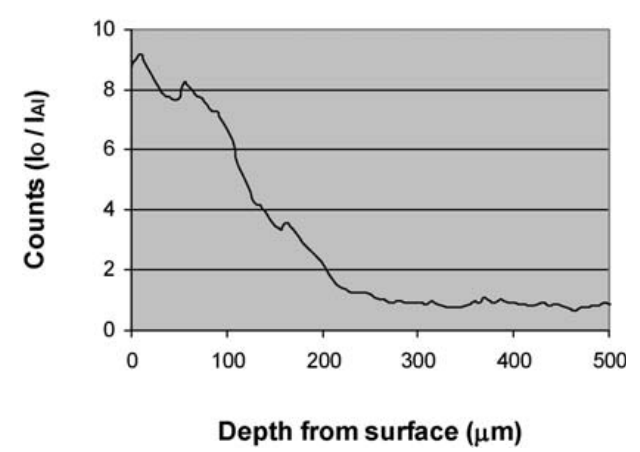

14 Oxygen concentration profile from surface to inside of $\mathrm{Ti}-48 \mathrm{Al}$ sample cast in $\mathrm{SiO}_{2}$ mould

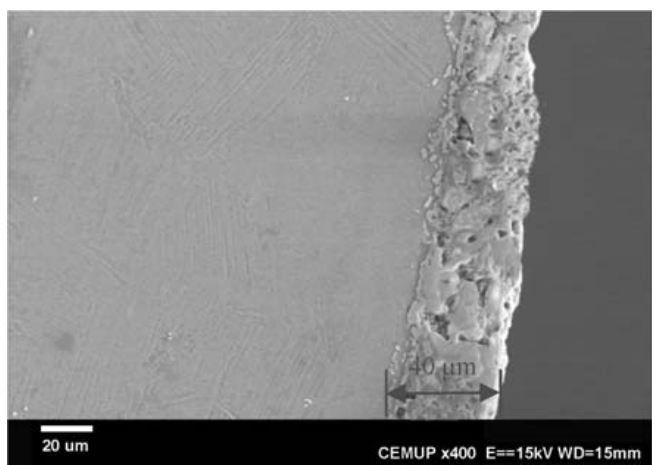

15 Microstructure of surface (metal/mould interface) of Ti-48Al sample obtained in SiO2 mould, showing presence of oxide layer $40 \mu \mathrm{m}$ thick

oxide layer is mainly an aluminium oxide (probably $\mathrm{Al}_{2} \mathrm{O}_{3}$ ) (zone 2 in Figs. 16 and 17), although other complex $\mathrm{Ti}$ and $\mathrm{Al}$ based oxides (zone 3 in Figs. 16 and 17) and other Ti and Si compounds (zone 4 in Figs. 16 and 17) were a small quantity of oxygen may also be present (zone 4 in Fig. 17), are also detected by the SEM/EDS spectrums of different zones of the layer. The poor thermodynamical stability of $\mathrm{SiO}_{2}$ enables the possibility of several metal-mould reactions to occur, involving either $\mathrm{Al}$ or $\mathrm{Ti}$, which usually lead to the formation of oxides and other compounds, according to reactions (2)-(5), for example

$$
\mathrm{SiO}_{2}+2 \mathrm{Ti}=2 \mathrm{TiO}+\mathrm{Si}
$$

$$
\begin{aligned}
& \mathrm{SiO}_{2}+2 \mathrm{Ti}=\mathrm{TiSi}+2 \mathrm{TiO} \\
& 2 \mathrm{SiO}_{2}+5 \mathrm{Ti}=\mathrm{TiSi}_{2}+4 \mathrm{Ti} \\
& 3 \mathrm{SiO}_{2}+11 \mathrm{Ti}=\mathrm{Ti}_{5} \mathrm{Si}_{3}+6 \mathrm{TiO}
\end{aligned}
$$

Close to the oxide layer, the $\mathrm{Al}$ concentration is lower than the average value of the sample (41 at.- $\%$ against 46.8 at. $-\%$ in $\alpha_{2}+\gamma$ and 49.8 at. $-\%$ against 53.9 at. $-\%$ in the interdendritic $\gamma$ phase). In some areas, the Al content is even lower, as in zone 1 of Fig. 16, where a Ti rich phase is present $(68 \cdot 3 \mathrm{Ti}, 31 \mathrm{Al}, 0 \cdot 6 \mathrm{Si}, 0 \cdot 1 \mathrm{Y}($ at.- $\%))$. The low $\mathrm{Al}$ content of those areas and the nature of the oxide layer suggest that the metal-mould interaction at the samples surface involves mainly reactions between Al and the mould materials, with Ti playing a secondary role on the interaction. This might be explained by the higher stability of $\mathrm{Al}_{2} \mathrm{O}_{3}$ when compared with $\mathrm{TiO}_{2}$, the most stable $\mathrm{Ti}$ oxide, that avoids, or makes more difficult, the reduction of the mould material by the titanium present on the metallic alloy.

Microhardness decreases from the surface to the interior of the samples, assuming constant values at different distances from the surface, in each microconstituent (Fig. 13). In $\alpha_{2}+\gamma$ microhardness decreases from $412 \mathrm{HV}$ at $25 \mu \mathrm{m}$ from the sample surface until values around $300 \mathrm{HV}$ at distances from the surface

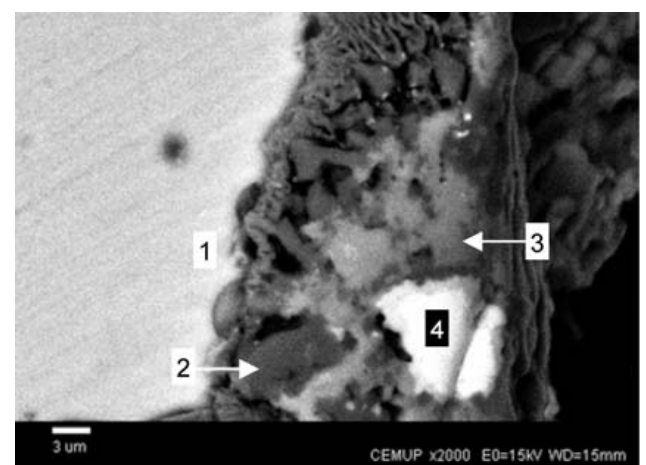

16 Microstructure of surface (metal/mould interface) of Ti-48Al sample obtained in $\mathrm{SiO}_{2}$ mould, showing presence of thick complex oxide layer 


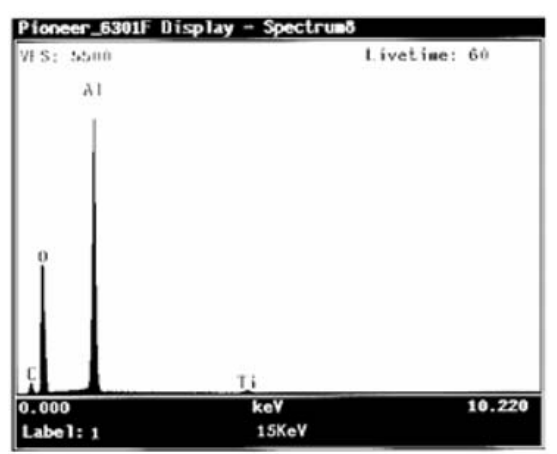

Zone 2

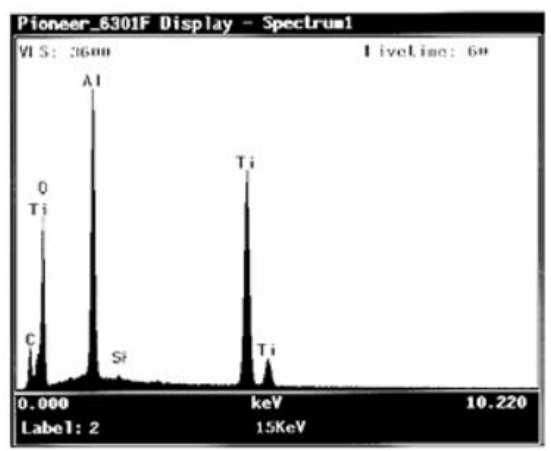

Zone 3

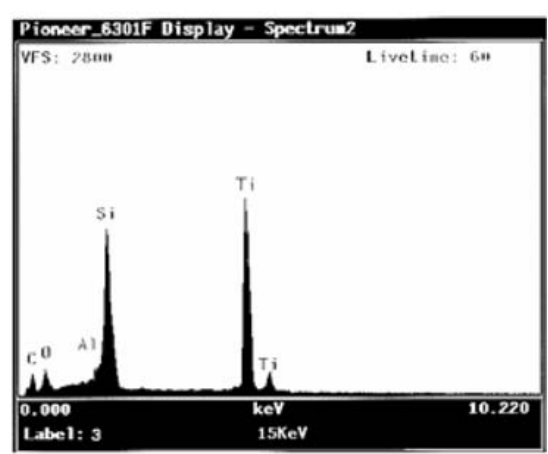

Zone 4

17 Spectrums (EDS) of zones 2, 3 and 4 referred in Fig. 16

$>250 \mu \mathrm{m}$. In the interdendritic $\gamma$ phase, microhardness decreases from $316 \mathrm{HV}$ at $25 \mu \mathrm{m}$ from the surface to 290 $\mathrm{HV}$ at distances $>50 \mu \mathrm{m}$. Owing to such variation, the 'alpha-case' extension in these samples is $\sim 250 \mu \mathrm{m}$, although it is much lower than that referred by Wictorin ${ }^{15}$ for commercially pure titanium cast in $\mathrm{SiO}_{2}$ based moulds $(500 \mu \mathrm{m})$. Although the presence of oxygen seems to be the main factor to contribute to the hardness increase in $\alpha_{2}+\gamma$, a possible contribution of the $\mathrm{Si}$ presence to such increase can not be excluded. However, its effect can not be confirmed or evaluated, as available data is not enough. In the interdendritic $\gamma$ phase, where oxygen has no influence in microhardness (as explained in section ' $\mathrm{ZrO}_{2}$ mould'), $\mathrm{Si}$ segregation and microhardness profiles do not match, although their behaviour is similar - Si concentration becomes constant at distances from surface $>150 \mu \mathrm{m}$, but microhardness values become constant at distances $>75 \mu \mathrm{m}$. The $\mathrm{Si}$ effect in microhardness is not known, however, such results suggest that for $\mathrm{Si}$ contents $<0.5$ at. $-\%$ (concentration at $75 \mu \mathrm{m}$ from the sample surface) its effect in microhardness can be neglected.

A layer of moulding material can be seen adherent to the sample surface, which removal is only possible by using a mechanical action. In some areas where roughness was possible to be measured, $\mathrm{Ra}$ was found to be $4 \mu \mathrm{m}$ (Fig. 8), although this value is nor representative of the overall surface condition.

\section{Conclusions}

1. The influence of the mould material in the contamination of $\mathrm{Ti}-48 \mathrm{Al}$ castings obtained in ceramic moulds is important. However, such contamination occurs only at the casting surface, until a distance from the surface that depends on the mould material and solidification time.

2. The main contaminants are oxygen and the metallic element present at the oxide used as mould material - $\mathrm{Si}, \mathrm{Zr}$ or $\mathrm{Y}$.

3. The chemical contamination leads to an increase in the casting microhardness, according to a profile that matches the segregation profile of oxygen in the same region.

4. The best results are achieved in moulds made of zirconia, with an inside (contact) coating of $\mathrm{Y}_{2} \mathrm{O}_{3}$. On samples obtained by using such moulds, the 'alpha-case' extension is $25 \mu \mathrm{m}$ and the microhardness at the surface is $306 \mathrm{HV}$ (maximum value), which agrees with the available references for the Ti-48Al alloys. Samples do not show evidence of metal-mould reaction and only very some small residues of mould material are detected adherent to the samples surface.

5. Casting in $\mathrm{ZrO}_{2}$ moulds leads to the formation of an $\mathrm{Al}_{2} \mathrm{O}_{3}$ layer at the samples surface, $\sim 15 \mu \mathrm{m}$ thick. Also a significant increase on microhardness in areas close to the surface is detected, which reaches a peak value of $362 \mathrm{HV}$, leading to an 'alpha-case' extension of $75 \mu \mathrm{m}$

6. Using $\mathrm{SiO}_{2}$ moulds leads to the formation of a complex oxide layer between 20 and $50 \mu \mathrm{m}$ thick, at the casting surface. A significant increase in microhardness on the same region leads to an 'alpha-case' extension of $250 \mu \mathrm{m}$, where microhardness values of $412 \mathrm{HV}$ can be found.

7. The surface finishing of the cast samples also depends on the mould material, although its variation is not very significant. The best results correspond to those samples cast in $\mathrm{Y}_{2} \mathrm{O}_{3}$ coated zirconia moulds, which surface roughness is $\sim 1.6 \mu \mathrm{m}$, followed by samples obtained in $\mathrm{ZrO}_{2} \quad(\mathrm{Ra}=2 \cdot 1 \mu \mathrm{m})$ and $\mathrm{SiO}_{2}$ moulds $(\mathrm{Ra}=4 \mu \mathrm{m})$.

8. The results obtained in this work suggest that it is possible to cast titanium aluminides with very low contamination and good surface finishing if $\mathrm{Y}_{2} \mathrm{O}_{3}$ is used as face coat of the moulds. The use of $\mathrm{ZrO}_{2}$ and $\mathrm{SiO}_{2}$ as mould material for the same purpose is not possible, because metal-mould reaction lead to high hardness values at the castings surface, chemical contamination of the alloy and surface oxidation.

\section{References}

1. T. S. Piwonka: Proc. 42th Annual Technical Meeting of the Investment Casting Institute, USA, 1994, Investment Casting Institute.

2. J. Barbosa: 'Elaboração de aluminetos de titânio por fusão de indução em cadinho cerâmico e vazamento em moldação cerâmica', PhD thesis, University of Minho, Portugal, 2001.

3. J. Barbosa, C. S. Ribeiro, O. M. N. D. Teodoro and A. C. Monteiro: Proc. EPD Cong. 2005 (2005 TMS Annual Meeting), San Francisco, CA, USA, February 2005, TMS

4. J. Schadlich-Stubenrauch, G. W. Dieckhues and P. R. Sahm: Proc. 27th Dedicated Conf. on 'New and alternative materials for the transportation industries', Aachen, Germany, November 1994.

5. J. Barbosa, C. S. Ribeiro and A. C. Monteiro: Mater. Sci. Forum, 2003, 426-432, 1933-1938.

6. J. Barbosa and C. S. Ribeiro: Intl J. Cast Met. Res., 2000, 12, 293301 
7. T. Sato, Y. Yoneda and N. Matsumoto: Trans. Jpn Foundr. Soc., 1992, 11, 27-33.

8. O. M. N. D. Teodoro, J. Barbosa, M. D. Naia and A. M. C. Moutinho: Appl. Surf. Sci., 2004, 231-232, 854-858.

9. J. Barbosa, O. M. N. D. Teodoro, A. M. C. Moutinho, C. S. Ribeiro and A. C. Monteiro: Mater. Sci. Forum, 2004, 455-456, 653-656.

10. A. Menand, A. Huguet and A. Nérac-Partaix: Acta Mater., 1996, 44, (12), 4729-4737.
11. D. J. Larson, C. T. Liu and M. K. Miller: Mater. Sci. Eng. A, 1997, A239, 220-228.

12. R. L. Saha, T. K. Nandy, R. D. K. Misra and K. T. Jacob: Metall. Trans. B, 1990, 21B, 559-566.

13. R. L. Saha, T. K. Nandy, R. D. K. Misra and K. T. Jacob: Bull. Mater. Sci., 1989, 12, (5), 481- 493.

14. R. C. Feagin: Proc. 19th Eur. Conf. on 'Investment casting', Brussels, Belgium, May 1986.

15. L. Wictorin, N. El-Mahallawy, M. A. Taha and H. Fredriksson: Cast Met., 1992, 4, (4), 182-187. 


\section{Authors Queries}

Journal: International Journal of Cast Metals Research

Paper: 795

Title: Characterisation of metal/mould interface on investment casting of $\gamma$-TiAl

Dear Author

During the preparation of your manuscript for publication, the questions listed below have arisen. Please attend to these matters and return this form with your proof. Many thanks for your assistance

\begin{tabular}{|l|l|l|}
\hline $\begin{array}{l}\text { Query } \\
\text { Reference }\end{array}$ & Query & Remarks \\
\hline 1 & $\begin{array}{l}\text { Author: Please provide the date } \\
\text { and place of the meeting. }\end{array}$ & \\
\hline 2 & $\begin{array}{l}\text { Author: Please comfirm the } \\
\text { authors' names. }\end{array}$ & \\
\hline 3 & $\begin{array}{l}\text { Author: Please provide the orga- } \\
\text { niser of the conference. }\end{array}$ & \\
\hline 4 & $\begin{array}{l}\text { Author: Please confirm the } \\
\text { authors' names. }\end{array}$ & \\
\hline 5 & $\begin{array}{l}\text { Author: Please provide the orga- } \\
\text { niser of the conference. }\end{array}$ & $\begin{array}{l}\text { Author: Please confirm the et al. } \\
\text { authors' names. }\end{array}$ \\
\hline 6 &
\end{tabular}

